\title{
Variation in the Number of Nipples in Wistar-Imamichi Rats
}

\author{
Hirofumi FUJITA, Yasumasa WAKAFUJI, Yoshio AGEMATSU \\ and Tomonori IMAMICHI* \\ Institute for Animal Reproduction, Omiya, Saitama 330, Japan, and \\ *Department of Physiology, Nippon Veterinary and Zootechnical \\ College, Musashino, Tokyo 180, Japan
}

(Received for publication : July 16, 1979)

\begin{abstract}
In order to determine heritability of accessory nipples, variations in the number of nipples were investigated in 13-week old female Wistar-Imamichi rats, maintained as a closed colony in the Institute for Animal Reproduction. Most of the females examined (93.32\%) had six pairs of nipples ; three in the pectoral and three in the abdomino-inguinal regions. Whereas, 229 out of 3606 rats had one accessory nipple each, 9 animals had 2 accessories, and 3 females were deficient of the pectoral nipple. Most of the accessory nipples were found either in the caudal and cranial regions of the third pectoral nipples or in the regions between the second and third abdomino-inguinal nipples. The frequencies for appearance of the accessory nipples were higher in the pectoral regions than those in the abdomino-inguinal ones, and also in the left side than in the right $(\mathrm{p}<0.01)$, respectively. In 208 out of 791 litters examined, 177 litters had only one sister-mate with accessory nipple, 29 litters had 2 sister-mates with accessories, and 2 litters had 3 sister-mates with accessories, respectively. The localization of accessory nipples of the sister mates within the litter was similar in most of the cases. Heritability of the appearance of accessory nipples was estimated to be 0.8074 by using the formula described by Falconer ${ }^{5}$.
\end{abstract}

\section{Wistar-Imamichi ラットの乳頭数の変異について}

\author{
藤田博文・若藤靖匡・上松嘉男・今道友則*
}

動物製殖研究所 日本獣医畜産大学生理学教室*

哺乳動物の乳頭数は Species を特徴づける有力な形質 であるが，乳頭数の多い動物種ではその数に変異がみら れる。また，乳頭数の多葟は多産の動物種では生産能力 と深いかかわりがあると考えられている $[2,3,17,18]$ 。 例えば，経斉動物としての豚においては乳頭数が乳仔の 発育や生死に関係しているとして日本種豚登録協会の審 査標準, 登録規定においても種豚の乳頭数は12個以上と 定められている $[13,14]$ 。また日本ホルスタイン登録協 会の番查標準では雄・雌ともに乳房のうち 1 乳区以上先 天的に欠如しているものは失格とされている $[15,16]$ 。

一方実験動物化されたマウス・ラットでは乳頭数は各
々10個，12個と記載されているが[11]，これらの動物種 が実験動物化される過程において乳頭数の変異の育種学 的配虑はほとんどされていなかった。しかしながら実験 動物においても, 生産効率を増大するためには泌乳可能 な乳頭数が増加することは望ましいことである。今道 $[4,10]$ は 1950 年以来, 東大農学部家畜生理学教室由来 Wistar 系ラットの量的形質の育種改良に努めて来た。 その結果安定した 4 日性周期を示し, 性質温順,かつ多産 ・哺育力に優れた発育良好な実験動物としてのWistarImamichi ラットを育成した。本報においては当研究所 で維持している Wistar-Imamichi ラットの集団に拉 
ける乳頭数の調査を行なったので報告する。

\section{材料およひ方法}

調査コロニー：対象コロニーは動物繁殖研究所・大宮 生産所に打いて1965年から撖重に選拢維持生産されてき た Wistar-Imamichi ラットの閉鎖集団である。

1）種親の選抜. 0 日齢における同腹仔数が11匹以上で あって，体重が 21 日齢（雄雌ともに30 g），90日齢（雌 $200 \mathrm{~g}$ ）および 120 日齢（雄350 g ）の発育基準に合格し た, 性質が温順で健康なものおよび雌は70〜90日齢で規 則正しく 4 日性周期を描いたものを選んだ。

2) 生産方式. 種雄 1 に対し種倠 $3 \sim 5$ 匹を 1 週間同居 させた後個別ケージに移した。出産日を 0 日龄として起 算し原則として 3 日齢で乳仔数を雌 6 , 雄 3 匹に調整し 21 日齢で離乳した。母体は 1 週間休息させた後, 再び交 配し雌ラットは 4 産まで使用した。

調査対象：1973年 6 月〜 1974年 5 月および1975年 3 月 〜1976年 2 月に生産された動物群を母集団として無作為 に雌3606匹を抽出し調査した。乳頭の観察は90日齢で肉 眼的に行ない, 乳腺組織との対応についての検討は行わ なかった。

判定方法：通常ラットにおける乳頭は左右一対をもっ 乙胸部第 I 〜第吕乳頭 $(\mathrm{I}$ st $\sim$ III rd pectoral mammary nipples), 鼠径部第 $\mathrm{I} \sim$ III 乳頭 $(\mathrm{I}$ st $\sim$ III rd abdomino-inguinal mammary nipples) と呼ばれ [11], この 6 対を保有する動物がもっとも一般的に認められる 型である。そこで本報ではこの 6 対を基本乳頭とし, 動 物自身の左と右に分け頭側から胸部第 I , 第 II , 第吕の 各乳頭, 鼠径部第 I, 第 II, 第吕の各乳頭とし, その位 置する場所を各乳頭域として記載した。基本乳頭は後述 する通り左右が対称的である。これに対し，非対称的な 乳頭が出現したとき基本乳頭数よりも多い場合にはそれ を副乳頭とし数の少ない場合には欠如乳頭とした。また 副乳頭が 左胸部第 I と第 II 乳頭の 間に存在する場合は $\mathrm{P}-\mathrm{L} \cdot \mathrm{I}-\mathrm{II}$ と示し 左胸部第 I 乳頭より 頭側の 場合は $\mathrm{P}-\mathrm{L} \cdot \mathrm{Cr}-\mathrm{I}$, 左胸部第吕 乳頭より尾側の場合は $\mathrm{P}-\mathrm{L}$ ・ Ca-III といらょうに記載した。また，無作為に選んだ 100 頭の雌を用い鼻端より左右乳頭までの距離を測定し 左右乳頭位置の対称性の検討の為に用いた。

統計処理の方法 : 基本乳頭に打ける左右乳頭位置の対 称性の検討にはStudent $の ~ t$ 検定を，その他の有意性の 検討の場合には $\chi^{2}$ 検定を用いた。また遺伝率の推定に はFalconer [5] の方法を適用した。なお同腹姉妹内に
Table 1. Distances between rhinal tip and each nipple in female Wistar-Imamichi rats $(n=100)$

\begin{tabular}{lrrr}
\hline $\begin{array}{l}\text { Site \& No. } \\
\text { of Nipples }\end{array}$ & & \multicolumn{2}{c}{ Distance from rhinal tip $(\mathrm{cm})$} \\
\cline { 3 - 4 } & & \multicolumn{1}{c}{ Left side } & \multicolumn{1}{c}{ Right side } \\
\hline Pectoral & I & $7.10 \pm 0.28$ & $7.03 \pm 0.25$ \\
& II & $9.07 \pm 0.32$ & $9.05 \pm 0.29$ \\
& III & $10.59 \pm 0.38$ & $10.50 \pm 0.34$ \\
Abdomino- & I & $15.27 \pm 0.48$ & $15.26 \pm 0.45$ \\
inguinal & II & $17.45 \pm 0.55$ & $17.41 \pm 0.53$ \\
& III & $18.80 \pm 0.57$ & $18.74 \pm 0.54$
\end{tabular}

Distance between rhinal tip and each nipple, measured in 100 animals, expressed as Mean \pm S.D., is not significantly different between left and right sides. These results indicate a symmetrical arrangement of the nipple in both sides of the body.

おける副乳頭出現部位の類似性の検討に際しては同腹姉 妹組内に执いて(1)副乳頭が 1 個所に出現した動物が 2 頭 （仮に動物 $\mathrm{A} ， \mathrm{~B}$ と呼ぶ）いた場合は動物 A と B たおけ る副乳頭出現部位の単一此較とし(2) 3 頭 (同 C, D, E) いた場合は C と D， Dと E， EとCの相互比較とした。 また(3)副乳頭が 1 個所に出現した動物が 1 頭（同F）と 2 個所（仮に副乳頭 $\mathbf{g}^{\prime} ， \mathbf{g}^{\prime \prime}$ と呼ぶ）に出現した動物が 1 頭（同G）いた場合は便宜的に後者（同G）を副乳頭 $\mathrm{g}^{\prime}$ および $\mathrm{g}^{\prime \prime}$ を別々にもつ動物（同 $\mathrm{G}^{\prime} ， \mathrm{G}^{\prime \prime}$ ) とみな し $\mathrm{F} と \mathrm{G}^{\prime} ， \mathrm{~F}$ と $\mathrm{G}^{\prime \prime}$ の相互比較とした。なお同腹姉妹 における副乳頭出現部位の類似率の計算は次式によった。 類似性のみられた姉妹組合せ数 $\times 100(\%)$ 姉妹組合せ総数

\section{成}

1) 基本乳頭に抢ける左右乳頭位置の対称性の検讨

基本乳頭から鼻端までの間の距離には対応する左右乳 頭間で有意差が認められなかった（Table 1)。このこ とは左右乳頭の位置に高い対称性があることを示す。副 乳頭に関してはほとんどが 1 側性であることから対称性 の検討はできなかった。

2 ) 変異乳頭の出現場所と出現率

調査対象動物 3606 頭のらち241頭（調査全頭数に対す る出現率；6.68\%）に乳頭数の变異を認めた。そのちち わけは副乳頭出現動物 238 頭 (同6.60\%), 乳頭欠如動物 3 頭（同0.08\%）であった。また 9 頭（同0.25\%）の動 物に 2 個の副乳頭出現があったため乳頭数にして延べ 
Table 2. Frequency and the site of the nipple variations observed in female Wistar-Imamichi rats

\begin{tabular}{|c|c|c|c|c|c|c|c|c|c|}
\hline \multirow{3}{*}{ Site No. } & \multicolumn{3}{|c|}{ Left side } & \multicolumn{3}{|c|}{ Right side } & \multicolumn{3}{|c|}{ Total of both sides } \\
\hline & \multirow{2}{*}{$\begin{array}{l}\text { No. of } \\
\text { Variation }\end{array}$} & \multicolumn{2}{|c|}{ Frequency } & \multirow{2}{*}{$\begin{array}{l}\text { No. of } \\
\text { Variation }\end{array}$} & \multicolumn{2}{|c|}{ Frequency } & \multirow{2}{*}{$\begin{array}{l}\text { No. of } \\
\text { Variation }\end{array}$} & \multicolumn{2}{|c|}{ Frequency } \\
\hline & & (A) & (B) & & (A) & (B) & & (A) & (B) \\
\hline P. I & 0 & 0 & 0 & 0 & 0 & 0 & 0 & 0 & 0 \\
\hline I - II & $1^{*}$ & 0.40 & 0.23 & 0 & 0 & 0 & 1 & 0.40 & 0.23 \\
\hline II & $4^{*}$ & 1.60 & 0.92 & $3^{* *}$ & 1.20 & 0.69 & $7\left(\begin{array}{l}4^{*} \\
3^{* *}\end{array}\right)$ & 2.80 & 1.62 \\
\hline II - III & $58^{*}$ & 23.20 & 13.40 & $35^{*}$ & 14.00 & 8.09 & 93 & 37.20 & 21.49 \\
\hline III & $2^{*}$ & 0.80 & 0.46 & $4^{*}$ & 1.60 & 0.92 & 6 & 2.40 & 1.39 \\
\hline Ca to III & $51^{*}$ & 20.40 & 11.79 & $16^{*}$ & 6.40 & 3.70 & 67 & 26.80 & 15.48 \\
\hline Total of $\mathrm{P}$. & 116 & 46.40 & 26.81 & $58\left(\begin{array}{c}55^{*} \\
3^{* *}\end{array}\right)$ & 23.20 & 13.40 & $174\left(\begin{array}{c}171^{*} \\
3^{* *}\end{array}\right.$ & 69.60 & 40.21 \\
\hline A. $\mathrm{Cr}$ to $\mathrm{I}$ & $2^{*}$ & 0.80 & 0.46 & 0 & 0 & 0 & 2 & 0.80 & 0.46 \\
\hline I & $1^{*}$ & 0.40 & 0.23 & $1^{*}$ & 0.40 & 0.23 & 2 & 0.80 & 0.46 \\
\hline I - II & $4^{*}$ & 1.60 & 0.92 & $5^{*}$ & 2.00 & 1.16 & 9 & 3.60 & 2.08 \\
\hline II & $2^{*}$ & 0.80 & 0.46 & $2^{*}$ & 0.80 & 0.46 & 4 & 1.60 & 0.92 \\
\hline II - III & $34^{*}$ & 13.60 & 7.86 & $20^{*}$ & 8.00 & 4.62 & 54 & 21.60 & 12.48 \\
\hline III & $1^{*}$ & 0.40 & 0.23 & $3^{*}$ & 1.20 & 0.69 & 4 & 1.60 & 0.92 \\
\hline Ca to III & $1^{*}$ & 0.40 & 0.23 & 0 & 0 & 0 & 1 & 0.40 & 0.23 \\
\hline Total of $\mathrm{A}$. & 45 & 18.00 & 10.40 & 31 & 12.40 & 7.16 & 76 & 30.40 & 17.56 \\
\hline Total & 161 & 64.40 & 37.21 & $89\left(\begin{array}{c}86^{*} \\
3^{* *}\end{array}\right)$ & 35.60 & 20.56 & $250\left(\begin{array}{r}247^{*} \\
3^{* *}\end{array}\right.$ & 100.00 & 57.77 \\
\hline
\end{tabular}

(A) : (No. of nipples with variation (additional or absent)/ total No. of nipples with variation) $\times 100$ (B) : (No. of nipples with variation on each site / total No. of principal nipples in animals) $\times 10000$ Principal nipples : 3 pairs on pectoral region and 3 on abdomino-inguinal. I, II, III : Site No. for principal nipples. I - II : Site between I and II. Ca : Caudal. Cr : Cranial. P: Pectoral.

A : Abdomino-inguinal ${ }^{*}:$ Accessory nipples. ${ }^{* *}:$ Absent nipples.

250 個の変異が確認された。変異乳頭出現状況を Table 2 に示した。副乳頭出現は左胸部第 II -III乳頭間の 58 例 （変異型中に占める出現頻度 $23.20 \%$ ）を最高に左胸部 第 I-II, 左鼠径部第 I, 第III, 第III後域および右鼠径 部第 I 乳頭域の各 1 例（同0.40\%）までであった。また その出現部位は副乳頭の出現を認めなかった左右胸部第 I 前域, 右胸部第 I - II 域, 右鼠径部第 I 前域, および 右鼠径部第後域を除いたほぼ全域に分布していた。さ らに 3 例 $(1.20 \%)$ の乳頭欠如動物において欠如部位は すべて右胸部第 II 乳頭であった。これら変異乳頭の出現 頻度には明らかに部位による有意差が琹められた。すな わら左側において右側の約 2 倍の乳頭数の変異が出現す る傾向が認められた（左側変異乳頭出現数 161 , 右側変 異乳頭出現数 $89, \mathrm{P}<0.01$ で有意差)。さらに胸部域に おいても鼠径部域の約 2 倍の変異乳頭が出現する傾向が 認められた（胸部域変異乳頭出現数 174, 鼠径部域変異 乳頭出現数 $76, \mathrm{P}<0.01$ で有意差)。

副乳頭が 2 倜所に出現した動物 9 頭についての出現部 位を一括して Table 3 に示した。両副乳頭共に沜部乳
頭域に認められたもの 5 頭, 左側乳頭域 3 頭, 右側乳頭 域 2 頭で，鼠径部乳頭域に 2 個とも位置していた個体は なかった。その他 4 頭の副乳頭は胸部乳頭域と鼠径部乳 頭域のそれぞれに 1 個づつ認められた。なお今回の調査 では同一個体で 3 個所以上の副乳頭出現例は認められな かった。

\section{3 ) 同腹姉妹内での副乳頭の出現状況}

調查対象雌動物 3606頭を構成する同腹姉妹組数は 791 組で, 1 組当りの平均姉妹頭数は $4.56 \pm 1.43$ 頭（平均士 S. D.) である。同腹姉妹組中 177 の姉妹組（全姉妹組数 に対する割合 $22.38 \%$ ）において 各組内に 1 頭づつ, 29 姉妹組（同 3.67\%）において 2 頭づつ，2姉妹組（同 $0.25 \%$ ）においてそれぞれ 3 頭づつ副乳頭を認めた。従 って言十208姉妹組（同26.30\%）が副乳頭を有しており残 る583姉妹組（同73.70\%）では副乳頭を有する動物の出 現を認めなかった。次いで副乳頭出現動物が 2 頭および 3 頭認められた 31 姉妹組内の副乳頭出現動物64頭につい て同腹姉妹同志の副乳頭出現部位の類似性について比較 検舎した（Table 4)。此較対象 31 姉妹組のらちわけは 
「統計処理の方法」の項の(1)に概当する副乳頭 1 個を持 つ動物が 2 頭認められた姉妹組 26 , (2)に概当する副乳頭 1 個を持つ動物が 3 頭認められた姉妹組 2 ，(3)概当す る副乳頭 1 個を持つ動物が 1 頭と 2 個を持つ動物が 1 頭 認められた姉妹組 3 であった。従って同腹姉妹内におけ る副乳頭出現部位の類似性比較のための姉妹同志の組合 せは延べ38組合せで延べ頭数67となった。出現部位の類 似性の比較では乳頭域を 4 区（左および右胸部乳頭域, 左および右鼠径部乳頭域）に大别して行なった。比較の 為の姉妹組合せの中で同一乳頭域に副乳頭の出現した姉 妹組19組合せ（延べ組合せ数に対して50.0\%）のうちわ けは左胸部乳頭域11組合せ（同28.95\%)，右胸部乳頭域 4 組合せ（同 $10.53 \%$ ）および左，右鼠径部乳頭域各々 2 組合せ（同 $5.26 \%$ ）であった。また左右を問わず副乳 頭の存在が胸部乳頭域にみられた姉妹 26 組合せ（延べ組
Table 3. Location of the accessory nipple in 9 rats with 2 accessory nipples

\begin{tabular}{|c|c|c|}
\hline \multirow{2}{*}{ Case } & \multicolumn{2}{|c|}{ Site for accessory nipples } \\
\hline & One & Another \\
\hline 1 & L.P. II - III & R.P. II - III \\
\hline 2 & L.P. II - III & L.A. II - III \\
\hline 3 & L.P. II - III & L.P. Ca to III \\
\hline 4 & L.P. Ca to III & R.P. Ca to III \\
\hline 5 & L.P. II - III & R.P. II - III \\
\hline 6 & L.P. II - III & L.A. I - II \\
\hline 7 & R.P. Ca to III & R.A. II - III \\
\hline 8 & R.P. II-III & R.A. I - II \\
\hline 9 & L.P. Ca to III & R.P. Ca to III \\
\hline
\end{tabular}

R : Right. L : Left. P : Pectoral. A : Abdomino-inguinal. I, II, III : Site No. for principal nipples. Ca : Caudal.

Table 4. Analysis of the region where accessory nipples appeared in sister-mates within each litter

\begin{tabular}{|c|c|c|c|c|c|c|c|c|c|c|c|c|c|c|}
\hline \multirow{3}{*}{ Group } & \multirow{2}{*}{\multicolumn{3}{|c|}{$\begin{array}{l}\text { No. of litters } \\
\text { with accessory nipples }\end{array}$}} & \multirow{3}{*}{$\begin{array}{l}\text { No. of pairs } \\
\text { of sister-mates } \\
\text { arranged }\end{array}$} & \multicolumn{10}{|c|}{ Regional pairs for accessory nipples detected } \\
\hline & & & & & \multirow{2}{*}{$\begin{array}{l}\text { L-P } \\
\& \\
\text { L-P }\end{array}$} & \multirow{2}{*}{$\begin{array}{l}\text { R.P } \\
\& \\
\text { R.P }\end{array}$} & \multirow{2}{*}{$\begin{array}{l}\text { L.P } \\
\& \\
\text { R.P }\end{array}$} & \multirow{2}{*}{$\begin{array}{l}\text { L-A } \\
\& \\
\text { L-A }\end{array}$} & \multirow{2}{*}{$\begin{array}{l}\text { R-A } \\
\& \\
\text { R-A }\end{array}$} & \multirow{2}{*}{$\begin{array}{l}\text { L-A } \\
\& \\
\text { R-A }\end{array}$} & \multirow{2}{*}{$\begin{array}{l}\text { L-P } \\
\& \\
\text { L-A }\end{array}$} & \multirow{2}{*}{$\begin{array}{l}\mathrm{R} \cdot \mathrm{P} \\
\& \\
\mathrm{R} \cdot \mathrm{A}\end{array}$} & \multirow{2}{*}{$\begin{array}{l}\text { L-P } \\
\& \\
\text { R-A }\end{array}$} & \multirow{2}{*}{$\begin{array}{l}\text { R.P } \\
\& \\
\text { L-A }\end{array}$} \\
\hline & One ${ }^{* *}$ & Two** & Total & & & & & & & & & & & \\
\hline 2 sister-mates* & $\begin{array}{l}26 \\
(52)^{* * *}\end{array}$ & $\begin{array}{c}3 \\
(6)\end{array}$ & $\begin{array}{l}29 \\
(61)\end{array}$ & 32 & 11 & 3 & 9 & 2 & 2 & 1 & 1 & 0 & 2 & 1 \\
\hline 3 sister-mates* & $\begin{array}{c}2 \\
(6)\end{array}$ & $\begin{array}{c}0 \\
(0)\end{array}$ & $\begin{array}{c}2 \\
(6)\end{array}$ & 6 & 0 & 1 & 2 & 0 & 0 & 1 & 1 & 0 & 1 & 0 \\
\hline Total & $\begin{array}{l}28 \\
(58)\end{array}$ & $\begin{array}{c}3 \\
(6)\end{array}$ & $\begin{array}{l}31 \\
(67)\end{array}$ & 38 & 11 & 4 & 11 & 2 & 2 & 2 & 2 & 0 & 3 & 1 \\
\hline
\end{tabular}

*: 2 or 3 sister-mates with accessory nipples within a litter

** : Number of accessory nipples seen in 2 or 3 sister-mates within a litter

***: Number in parenthesis represent total number of animals with accessory nipples

L-P : Left pectoral region. R.P : Right pectoral. L-A : Left abdomino-inguinal. R-A : Right abdominoinguinal.

合せ数に対して $68.42 \%)$, 鼠径部乳頭域のもの 6 組合せ

(同15.79\%), 胸部・鼠径部乳頭両域にわたった姉妹 6 組合せ（同 $15.79 \%$ ）であり，胸部の占める割合が有意 に多かった（ $\mathrm{P}<0.01 ）$ 。左右間の比較では左側乳頭域 15 組合せ (同 $39.47 \%$ ), 右側乳頭域 6 組合せ（同 15.79 \%) 左側・右側乳頭両域にわたった姉妹 19 組合せ（同 $50.00 \%$ ）であり右側乳頭域を共通とするものが少くな る傾向がみられた $(0.05<\mathrm{P}<0.10)$ 。また出現部位で まったく共通性の認められないものは 4 組合せ(同10.53 \%)のみであり，まったく同一部位に出現した姉妹11組 合せ (同28.95\%) を含め残る34組合せ（同89.47\%）に おいては副乳頭の出現部位に類似性が認められた。

4 ）遺伝率の推定
変異乳頭出現に関する遺伝性の検討のための Falconer [5]闇值形質に拈ける遺伝率推定方法を準用した。 すなわち今回の調査の一般集団における変異乳頭動物出 現率は6.68\% (241 頭/3606 頭)，近縁集団つまり同腹動 物における変異乳頭動物出現率は $23.63 \%$ (241 頭/1020 頭）であり Falconer [5] の付表より

$$
\begin{aligned}
x_{g} & =1.5012 \\
x_{r} & =0.7183 \\
\mathrm{a} & =1.9392 \\
\mathrm{r} & =1 / 2
\end{aligned}
$$

従って遺伝率 $\mathrm{h}^{2}$ は

$$
\mathrm{h}^{2}=\frac{x_{g}-x_{r}}{\mathrm{ra}}=\frac{1.5012-0.7183}{1 / 2 \times 1.9392}=0.8074
$$


であった。

\section{考察}

実験小動物として洲用されるラットでは胸部 3 乳腺域, 腹鼠径部 3 乳腺域をもち, 乳頭は各乳腺域に 1 個づつ計 12乳頭が定説となっており他の多産動物種において認め られるような変異には富んでいないと一般に考えられて いる[11]。しかし Myers [12] は乳腺管および乳頭に 関する研究報告の中で，また Henneberg [9] は胎児に おける乳器の発育に関する研究の中で各々少数例ではあ るがラットにお汁る乳腺数および乳小丘数の变異につい て詳細な記述を行なっている。Frank ら［6]もまた乳 腺の発育促進に関する実験の中でラットに10～14の乳房 (breasts) があることを記載しているが変異の部細につ いては明らかではない。 Myers [12] は観察動物100例 中80例ではいわゆる正常乳頭数を持ち，1 例のみに過剩 乳頭（出現部位は左側胸部第而乳頭の直後），12 例には 右側胸部第 II 乳頭が久如， 7 例には左右胸部第 II 乳頭の 欠如を観察し過剩乳頭よりさしろ欠如乳頭例が多かった ことを報告している。さらに Henneberg [9]は14から 15日粭の胎仔28例の観察で 5 例に過剩乳小丘を認めた。 それはすべて胸部に出現し正常のものより小さく，4 例 が第 II と第吕胸部乳小丘の間に出現，1 例は第 III 乳小丘 の直後であった。しかし成熟動物では，150 例中過剩乳 頭例は胸部第而乳頭の直後に出現したわずか 1 例にすぎ なかったが，この動物では同時に鼠径部第 I 乳頭が久如 していた。

今回の著者らの成熟雌 Wistar-Imamichi ラット群 における調査結果からは過剩および久如乳頭を持つ，い わゆる变異乳頭出現動物は必ずしも少なくなく調査動物 の6.68\%におよんだ。この事実はこのラットにおいて乳 頭数が未だ固定された形質ではなく，遺伝的背景の相違 により乳頭数が増減する可能性を示唆している。

また今可の調査において副乳頭出現部位が特定乳頭域 のみに限局する現象は観察されなかったが，辺縁部乳頭 域（胸部第 II 乳頭より前部および腹鼠径部第而乳頭の後 部）においてはまったく出現をみないか非常に低頻度で あり，胸部第 II-III乳頭域，第III乳頭後域および腹鼠径 部第 II-III乳頭域において多発する傾向が認められた。 前述 Myers [12], Henneberg [9]らもまた胸部第III 乳頭前後域に過剩乳頭を認めている。さらに乳頭の欠如 部位に関して Myers は胸部第 I乳頭の片側あるいは画 側の久如を観察し，Henneberg は腹鼠径蔀第 I 乳頭の
久如を認めており，今回の著者らの調查でも全調査頭数 のわずか $0.08 \%$ （ 3 例）ではあったが胸部第 II 乳頭の片 側欠如を確認している。

また副乳頭の出現率を左右について比較すると左側乳 頭域に多発する傾向が慧められた。同様な現象につい ては Anderson ら [1] がゴールデンハムスターにおい て，また Poonacha ら [19] がインディアンシープ 7 品種と 2 交雑種について報告している。動物種を異にす るが，かかる現象からは乳頭出現の有無ならびにその位 置决定にあずかる遺伝因子の存在が推測される。

多胎動物における乳頭数の遺伝性については豚におい て数多くの研究があり遺伝率の推定が行なわれている。 Hanset ら [7]は Piétrain 種と Belgian Landrace 種を用いた実験で平均遺伝率が各々0.46，0.34であった ことを報じ Oluyemi ら［17］は Landrace 種と Large White 種を用いた実験から $0.18 〜 0.78$ の遺伝率を推定 している。また武富ら [20]は豚乳頭数の遺伝に関する 公範な研究の中で Middle White 種および Berkshire 種について遗伝率を推定し0.02〜0.62の值であったとし ている。また Hanset ら [8]は1961 年から 1971 年に かけて Piétrain 種を用い多乳頭化への選抜育種を行な い乳頭数が13.17から13.59へ増加し12個以下の動物が減 少したことを報じている。しかし豚以外の多胎動物での 乳頭数の遺伝性に関する報告は比較的少ない。著者らが ラット変異乳頭出現の有無を閾值形質と考えて Falconer [5] の選抜反応を利用した方法を用い遺伝率を推定 した結果では0.8074であり一般の豚に扎いて推定された 值よりやや大きい值を示している。この值は本ラット乳 頭数における表型選抜の有效性を示唆している。従って 今後副乳頭と乳腺あるいは哺乳力との関連性について検 討をしつつ選抜対象形質の一つに乳頭数を加える考虑が 必要であろう。なお副乳頭の生理機能および哺育力に関 する検討は現在計画中である。

\section{要 約}

ラットの乳頭数は一般に胸部, 腹鼠径部各 3 対計 12 個 であるが，乳腺を伴なら乳頭数の多い動物を育種するこ とができれば哺育能力を高め，生産效率を向上させるこ とに結び付く可能性が期待できる。この様な見地から， Wistar-Imamichi ラットの乳頭数の変異（副および久 如乳頭出現の有無）について調査検討を行った。

調查総数 3606 頭のうち 241 頭（6.68\%）に乳頭数の変 晎が認められた。241䫓中229㖽に 1 個，9頭に 2 個の副 


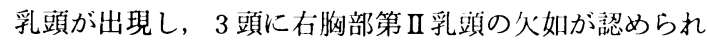
た。

副乳頭出現部位はほぼ全域にわたったが，特に胸部第 III乳頭の前後域・腹鼠径部第 II-III乳頭域で多く出現し， 左右胸部第 I 乳頭前域・右胸部第 I - II 乳頭域および右 腹鼠径部第 I 乳頭前域にはみとめられなかった。

変異乳頭は腹鼠径部よりも胸部で, 右側よりも左側乳 頭域に多く出現する傾向が認められた（ $\mathrm{P}<0.01 ） 。$

調査対象の同腹姉妹組数は791でそのうち177組は各組 内に 1 頭づつ， 29 組には 2 頭づつ， 2 組には 3 頭づつの 動物が副乳頭を有し他の 583 組には副乳頭出現動物は認 められなかった。副乳頭出現動物が 2 頭以上みつかった 同腹姉妹組（31組）における姉妹同志（38組合せ）での 副乳頭出現部位の類似率は $89.47 \%$ であった。

変異乳頭出現に 関して遺伝率を推定したところ $\mathrm{h}^{2}=$ 0.8074であった。したがって, 表型選抜による育種の可 能性が示㖫された。

本研究の推進を援助いただいた動物慗殖研究所大山優子夫人に 感謝する。また有益な御助言をいただいた東北大学医学部信永利 馬助教授に対し深甚な謝意を表する。

本研究の一部は文部省科学研究費特定研究「実験動物 の純化と開発」課題番号012212によって行った。

\section{文献}

[1] Anderson, R. R., and Sinha, K. N. (1972). Number of mammary glands and litter size in golden hamster. J. Mammal., 53, 382-384.

[2] Bicanin, M. (1966). Correlation between the number of teats in the sow and the number of piglets born live, in relation to udder asymmetry. Agron. Glasn., 17, 603-606; Dairy Sci., Abstr., 29, 669.

[3] Burkat, V. P. (1967). The selection of pigs for teat number. Svinovodstvo, Mosk., 21, 40-42: Anim.
Breed. Abstr., 36, 467.

[4]動物繁殖研究所 (1978). 動物繁殖研究所の実験動物.

[5] Falconer, D. S. (1965). The inheritance of liability to certain diseases, estimated from the incidence among relatives. Ann. Hum. Genet., 29, 51-76.

[6] Frank, R. T., and Unger, A. (1911). An experimental study of the causes which produce the growth of the mammary gland. Arch. intern. Med., 7, 812-838.

[7] Hanset, R., et Camerlynck, R. (1974). L'h '́ritabilit ¿ du nombre de mamelles chez le Porc de Pictrain et le Porc Landrace Belge. Ann. Génśt. Síl. Anim., 6, 91-102.

[8] Hanset, R., et Widar, J. (1975). L'efficacitá de la sálection pour le nombre de mamelles chez le Porc de Piśtrain. Ann. Génśt. Sál. Anim., 7, 91-97.

[9] Henneberg, B. (1899). Die erste Entwicklung der Mammarorgane by der Ratte. Anat. Hefte., 13, 1-68.

[10）今道友則(1961). 繁殖生理学および内分泌学研究に適する 生理的特徴を目標とした Wistar-Imamichi rat の吉成に ついて. 日本臨牀, 19, 99-109.

[11］望月公子・藤岡俊健・鬼頭純三 (1968), 乳器の形態と構 造. 泌乳, 星冬四郎・内藤元男編, 東大出版会, 東京, $\mathrm{p}$. $1-36$.

[12] Myers, J. A. (1916). Studies on the mammary gland. I. The growth and distribution of the milk-ducts and the development of the nipple in the albino rat from birth to ten weeks of age. Am. J. Anat., 19, 353-390.

[13] 日本種豚登録協会 (1976). 種豚登録規定.

[14] 日本種豚登録協会 (1976). 豚の体格審查標準。

[15］曰本ホルスタイン登録協会 (1965). Holstein 種牡牛審查 標淮.

[16] H本ホルスタイン登録協会 (1965). Holstein 種牝牛審查. 標準.

[17] Oluyemi, J. A., and Babtola, E. (1973). The heritability and the economic importance of nipple num bers in swine at the University of Ibadan. E. Afr. Agric. For. J., 38, 215-217.

[18] 大島正尚 (1968). 乳頭. 繁殖学辞典, 星冬四郎編, 文永 堂, 東京, 147-148.

[19] Poonacha, K. B., and Prabuhu, S. S. (1970). Variation in multiple nipples in some breeds and crosses of Indian sheep. Ind. J. Anim. Sci., 40, 650-660.

[20］武富万治郎・丹羽太左衛門・宮園幸男 (1954). 豚の 乳頭 数の遺伝に関する研究. 農技研報告 $\mathrm{G}, 9,29-41$. 